\title{
Danger of GLOFs in the Mountain Areas of Kazakhstan
}

\author{
Viktor Blagovechshenskiy, Vasiliy Kapitsa and Nikolay Kasatkin \\ Institute of Geography, Ministry of Education and Science, Almaty 050010, Kazakhstan
}

Received: February 15, 2015 / Accepted: March 05, 2015 / Published: March 20, 2015.

\begin{abstract}
The presentation describes the methods and shows the results of GLOFs' danger estimation in Ile and Zhetysu Alatau ranges (Kazakhstan). The catalogues of glacial lakes were made following the results of satellite images processing. The catalogue contains the data of 186 glacial lakes in Ile Alatau and 577 lakes in Zhetysu Alatau. According to the bathymetric data of 35 glacial lakes the dependences of volume on lake's area for proglacial and moraine lakes were developed and lake's volumes were calculated. There are 32 lakes in Ile Alatau and 110 lakes in Zhetysu Alatau with water volume more than $100,000 \mathrm{~m}^{3}$. The most hazardous lakes have the following characteristics: 1) the lake volume exceeds $100,000 \mathrm{~m}^{3}$, (2) the lake is proglacial, (3) the dam is a young moraine with an ice core, (4) there are sites with the steep of more than $15^{\circ}$ spreading for more than $500 \mathrm{~m}$ down the valley, and (5) there are important non-protected objects in the mudflows affected area. There are 14 the most hazardous glacial lakes with very high level of GLOF danger: 6 lakes in Ile Alatau and 8 lakes in Zhetysu Alatau.
\end{abstract}

Key words: Glacial lakes, outburst floods, mudflow hazard assessment.

\section{Introduction}

Changes of climate and corresponding reduction of glaciers cause formation of glacial lakes in the mountain areas of the world that leads to increasing risk of mudflows caused by outbursts of these lakes [1-6].

Glacial lakes are usually difficult to access. So it is necessary to use satellite images for studying glacial lakes. But aerial visual researches and field studies are often very useful [1, 7-9]. Satellite images and topographic maps allow obtaining morphometric data of glacial lakes. The gained data offer an opportunity for hazard assessment of glacier lake outburst floods and debris-flows related to this flood.

The problems of GLOFs' (glacial lake outburst flood) danger assessment are discussed in the works [10-13]. The most developed one is the method of German scientists $[7,14]$ used for glacial lakes of the North Tien Shan.

Intensive reduction of glaciers and forming of

Corresponding author: Blagovechshenskiy Viktor, Dr., research fields: natural hazards, natural risk assessment. E-mail: victor.blagov@mail.ru. glacial lakes are observed in Ile and Zhetysu Alatau from the middle of 20th century. The glaciers area reduced to $117 \mathrm{~km}^{2}(40.8 \%)$ at the North slope of Ile Alatau and to $217 \mathrm{~km}^{2}$ (31.4\%) in Zhetysu Alatau during the last 50 years. Several disastrous mudflows connected with GLOFs occurred during the last 50 years in Ile and Zhetysu Alatau ranges in Kazakhstan [5, 13, 16-20]. Disastrous mudflows caused by GLOFs occurred in 1963 (Yesik), 1973 (Tuyuksu), 1980 (Kaskelen), 1970 and 1978 (Aksu), 1982 (Sarkan), 1979, 1993 and 2014 (Sredniy Talgar).

The aim of this study is to investigate the potential dangerous glacial lakes in Kazakhstan.

\section{Background and Study Area}

The mountain ranges of Ile Alatau (the former name was Zailiyskiy Alatau) and Zhetysu Alatau (the former name was Dzungarskiy Alatau) are located in Central Asia at the border between Kazakhstan, Kyrgyzstan and China (Fig. 1). These ranges rise from contiguous planes at an elevation of about $800 \mathrm{~m}$ above sea level to nearly 5,000 $\mathrm{m}$ asl (Ile Alatau) and 4,600 $\mathrm{m}$ asl (Zhetysu Alatau). Many villages, Almaty 
City with a million of inhabitants and important ski resorts such as Chymbulak and Akbulak are situated at the mountains.

The territory of glacial and periglacial zones of the North slope of Ile Alatau and Kazakh part of Zhetysu Alatau was studied. The studying territory is located between $42^{\circ} 50^{\prime}$ and $43^{\circ} 10^{\prime} \mathrm{N}$, and between $76^{\circ} 30^{\prime}$ and $77^{\circ} 40^{\prime} \mathrm{E}$ in Ile Alatau; and between $44^{\circ} 28^{\prime}$ and $45^{\circ} 15^{\prime} \mathrm{N}$, and between $79^{\circ} 10^{\prime}$ and $81^{\circ} 10^{\prime} \mathrm{E}$ in Zhetysu Alatau. The studying territory accounts 1,200 sq. $\mathrm{km}$ in Ile Alatau and 3,200 sq. km in Zhetysu Alatau. The lower border of a glacial zone with present glaciers lays at $3,500 \mathrm{~m}$ in Ile Alatau, and at 3,200 $\mathrm{m}$ in Zhetysu Alatau. The periglacial zone with moraines, glacial lakes and permafrost descend to $3,100 \mathrm{~m}$ in Ile Alatau, and to $2,800 \mathrm{~m}$ in Zhetysu Alatau.

\section{Data and Methods}

To make a catalogue of glacial lakes we used
Landsat satellite images with connection to panchromatic channel that allows improving resolution of satellite images up to $15 \mathrm{~m}$, as well as Aster images. The survey was held in the middle August of 2002. We also used a digital relief model of Aster satellite with the resolution of $30 \mathrm{~m}$ and topographical maps with the scale of $1: 50,000$ (Table 1).

Glacial lake identification was made manually and using satellite images. The results were checked (tested) during aerial visual researches from a helicopter. Morphometric characteristics of the lakes were determined using satellite images and topographical maps by ArcGis 9.3.1 programme. The stuff of Kazakhstan Mudflow Protection Service and Institute of Geography measured the area and water volume of 35 lakes using echo sounder and GPS-receiver. Comparison of the lakes' areas measured in the field with the data obtained from the satellite images showed they differ not more than $5 \%$.

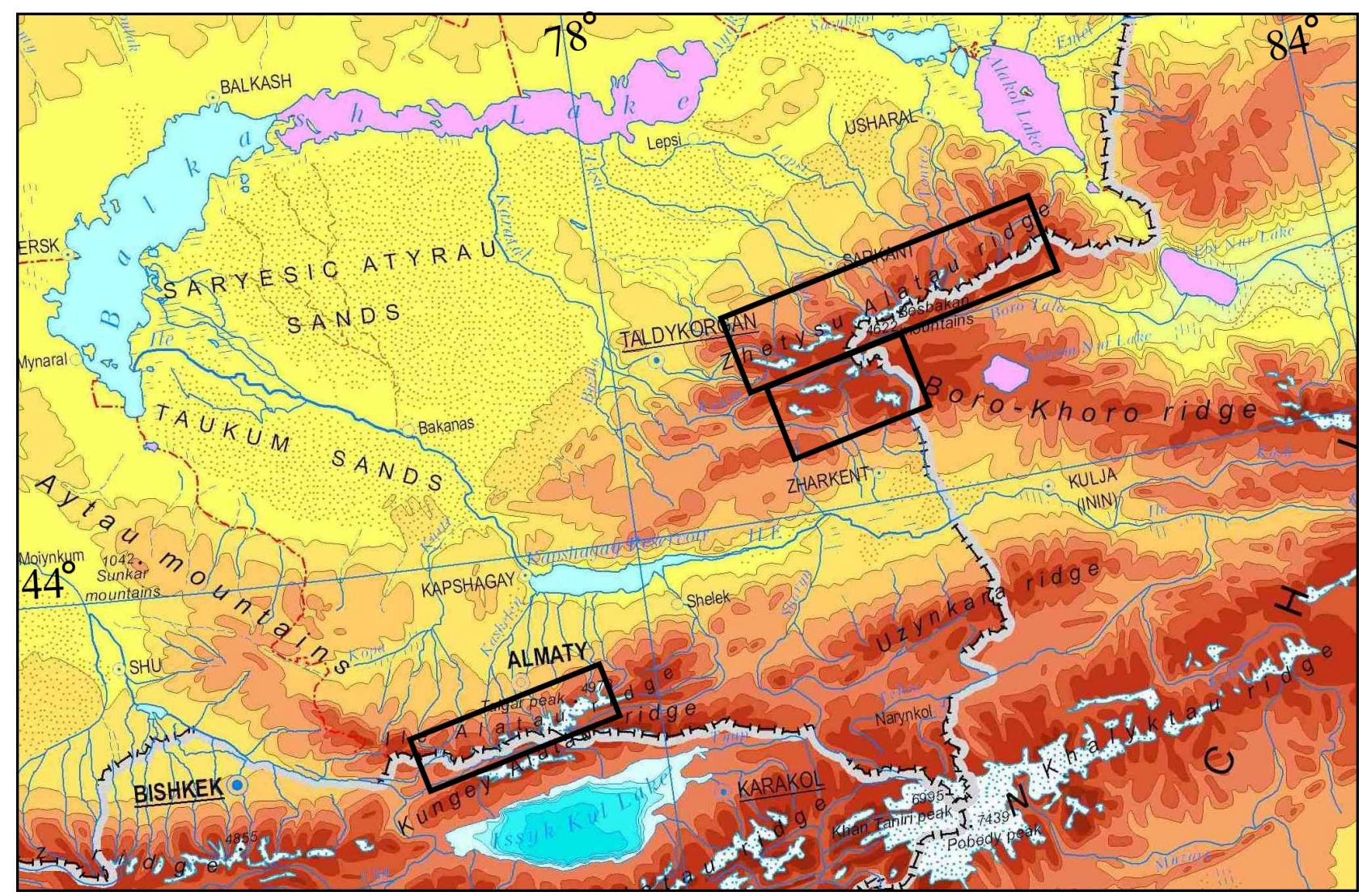

Fig. 1 Location of the study area. 
Table 1 The used satellite data.

\begin{tabular}{llll}
\hline Satellite and Sensor & Date & Resolution, $\mathrm{m}$ & Source \\
\hline Aster Terra & $08-09.2002$ & 15 & USGS \\
Landsat 7 ETM+ & $08-09.2002$ & 15,30 & USGS \\
Landsat 5 TM & 08.2002 & 30 & USGS \\
Aster DEM & 2011 & 30 & gdem.aster \\
SRTM & 2000 & 90 & srtm.csi \\
\hline
\end{tabular}

The catalogues of glacial lakes were made following the results of satellite images processing with added aerial visual observations. The catalogues display the data concerning geographical coordinates of the lake, its height, area, and type. The catalogue contains the data of 186 glacial lakes in Ile Alatau and 577 lakes in Zhetysu Alatau. As one of the most important characteristics of GLOF's danger is water volume we tried to value it. According to the data gained during bathymetric surveys of 35 glacial lakes in Ile Alatau we found dependences of volume on lake's area separate for proglacial and moraine lakes (Fig. 2). These dependencies could be approximated by the equations:

$V=1.604 F^{1.428}$, for proglacial lakes, and

$V=0.636 F^{1.489}$, for moraine lakes.
Here $F$ is lake's area, thousand $\mathrm{m}^{2}, V$ is lake's volume, thousand $\mathrm{m}^{3}$.

G. Glazirin et al. [19] used a similar equation to estimate glacial lake volumes in the Uzbekistan Mountains

The value of approximation accuracy for these dependencies makes $R^{2}=0.92$ for proglacial lakes, and $R^{2}=0.89$ for moraine lakes. Standard deviation of the measured volumes from the calculated ones is $25 \%$. Water volumes in glacial lakes were accounted according to these dependencies. Table 2 shows distribution of the lakes' number according to water volume.

Among 186 glacial lakes in Ile Alatau, 159 ones have the volume of more than $1,000 \mathrm{~m}^{3}, 93$ lakes have the volume of more than $10,000 \mathrm{~m}^{3} .32$ lakes have the

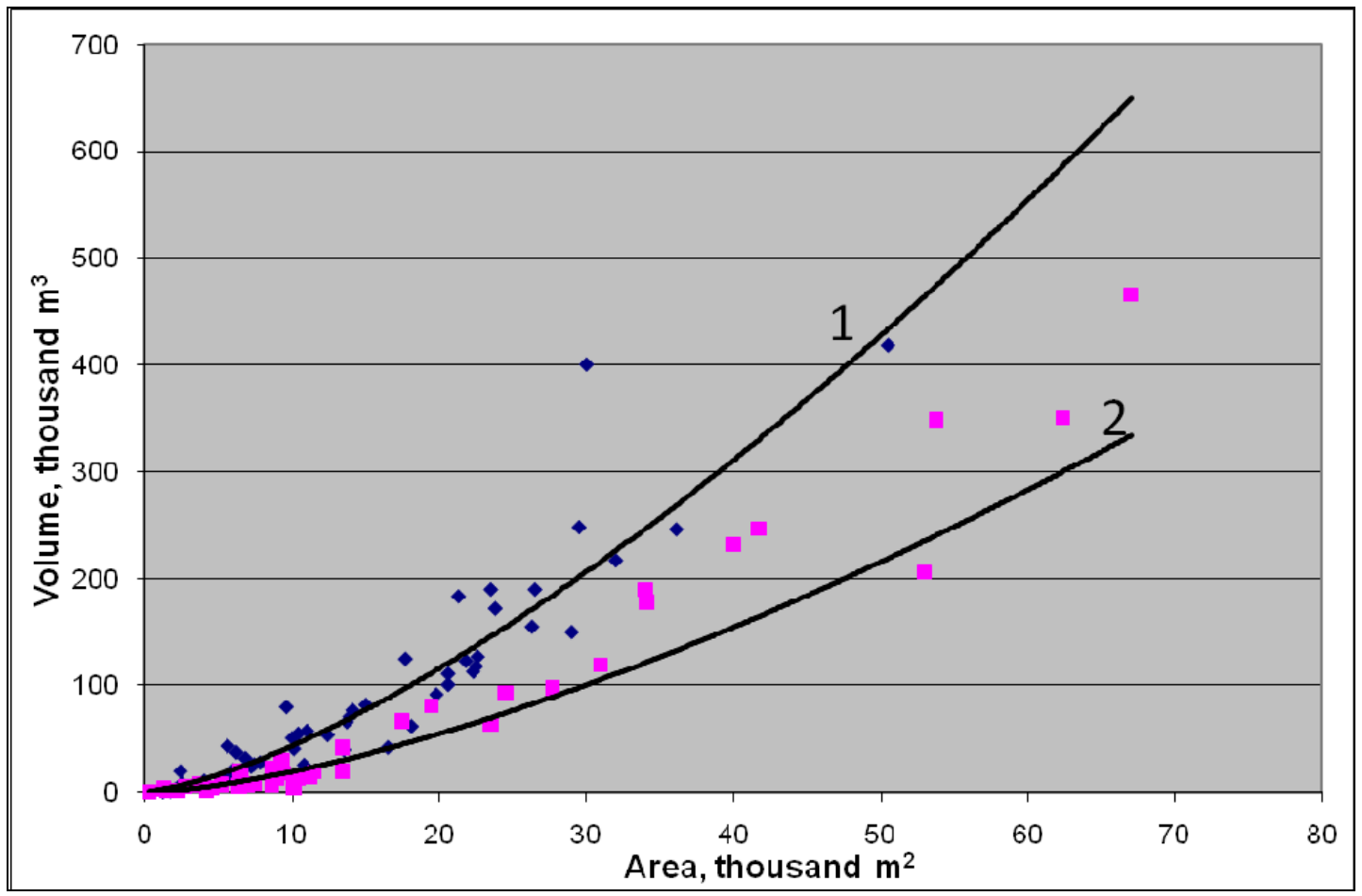

Fig. 2 Dependences of lake volume on lake area. 1-proglacial lakes, 2 -moraine lakes. 
Table 2 Distribution of the lakes' number according to water volume.

\begin{tabular}{|c|c|c|c|c|c|c|c|c|}
\hline \multirow{2}{*}{$\begin{array}{l}\text { Mountain } \\
\text { region }\end{array}$} & \multirow{2}{*}{ Index } & \multicolumn{7}{|c|}{ Lake's volume, thousand cu. m } \\
\hline & & $<1$ & $1-5$ & $5-10$ & $10-50$ & $50-100$ & $100-200$ & $>200$ \\
\hline \multirow{2}{*}{ Ile Alatau } & Number & 27 & 51 & 15 & 43 & 18 & 17 & 15 \\
\hline & Percentage, $\%$ & 14.8 & 27.9 & 8.2 & 23.5 & 8.2 & 9.3 & 8.2 \\
\hline \multirow{2}{*}{$\begin{array}{l}\text { Zhetysu } \\
\text { Alatau }\end{array}$} & Number & 44 & 116 & 65 & 198 & 53 & 39 & 62 \\
\hline & Percentage, $\%$ & 7.6 & 20.1 & 11.3 & 34.3 & 9.2 & 6.8 & 10.7 \\
\hline
\end{tabular}

volume from 100,000 till 500,000 $\mathrm{m}^{3}$. Among 577 glacial lakes in Zhetysu Alatau, 533 ones have the volume of more than $1,000 \mathrm{~m}^{3}, 452$ lakes have the volume of more than $10,000 \mathrm{~m}^{3} .101$ lakes have the volume of more than $100,000 \mathrm{~m}^{3}$. Nine lakes have the volume from 1 till 3.7 million $\mathrm{m}^{3}$.

All glacial lakes were divided for two categories. They are proglacial and moraine ones. Proglacial lakes have contact with a glacier or are located close to a glacier's end. A lake depression of such lakes is usually cup-shaped. Ice water from a glacier comes straight in a lake, so the water during ablation period is muddy. It is well seen at the satellite images. Young moraines serve as dams for proglacial lakes. Such moraines have an ice core and are affected by intense thermokarst processes. Proglacial lakes are actively developing now.

Moraine lakes are located at old moraines. A lake depression is often plate-shaped. Moraine lakes are located rather far from glaciers and don't have straight hydrological connection with them. Water in such lakes is clean. Dams are formed from frozen soil but don't contain large massifs of buried ice.

\section{Assessment of GLOFs Hazard}

To assess the hazard of GLOF, four factors are kept in mind. They are (1) lake's characteristics, (2) dam's characteristics, (3) characteristics of the valley below the lake, and (4) potential damage from the mudflow. One of the most important factors for analysis of potential GLOF's danger is water volume in the lake. The data concerning GLOFs in Ile Alatau show the volume of the mudflow formed after the lake's outburst can exceed in 10 times the volume of water resulting from the lake. The specialists from
Kazakhstan Mudflow Protection Service consider a glacial lake to be danger if its volume exceeds $100,000 \mathrm{~m}^{3}[5,18]$.

Possibility of lake's outburst mainly depends from the dam's stability. The lakes dammed by young moraines with an ice core show the highest possibility of outburst. Proglacial lakes are mostly often among them.

Flood resulting from a lake outburst transforms into a mudflow only in the case when the valley below the lake has steep sites with slopes of more than $15^{\circ}$ spreading for more than $500 \mathrm{~m}$.

Potential damage form outbursting mudflows depends on existence of social and economic objects in its impact area and protection level of these objects.

So maximum potential outburst hazard is observed in the case if (1) the lake volume exceeds $100,000 \mathrm{~m}^{3}$, (2) the lake is proglacial, (3) the dam is a young moraine with an ice core, (4) there are sites with the steep of more than $15^{\circ}$ spreading for more than $500 \mathrm{~m}$ down the valley, and (5) there are important non-protected objects in the mudflows affected area.

\section{Results}

We found 14 the most hazardous glacial lakes: 6 lakes in Ile Alatau and 8 lakes in Zhetysu Alatau. Hazardous lakes in Ile Alatau are located in the valleys of Kaskelen, Big Almaty, Little Almaty, Talgar, and Yesik rivers.

The lake in Kaskelen valley is located at the height of 3,430 $\mathrm{m}$ at the buried ice massif. It has the volume of $120,000 \mathrm{~m}^{3}$. This lake has already outburst in 1980 . There are roads and recreation zone in the mudflow impact area. The Kaskelen town is located at the foothills and protected by the dam. 
The Kumbel lake in Big Almaty valley is adjacent to the Sovetov glacier. It is located at the height of $3,550 \mathrm{~m}$ and has volume of $250,000 \mathrm{~m}^{3}$. Outburst of this lake can lead to formation of the mudflow with the volume of several millions $\mathrm{m}^{3}$. There are roads, houses, hotels, and restaurants in the mudflow affected area. Almaty City is protected by the dam.

The Mametova lake in Little Almaty valley is located under the same-named glacier at the height of $3,600 \mathrm{~m}$. Its volume is $180,000 \mathrm{~m}^{3}$. In the case of the lake's outburst the mudflow will pass Little Almaty valley till Medeu dam at the height of $1,800 \mathrm{~m}$. The infrastructure will be damaged.

There are three hazardous lakes in Talgar river basin. They are the Toguzak lake with the volume of $206,000 \mathrm{~m}^{3}$ at the height of $3,480 \mathrm{~m}$, the Kalesnika lake with the volume of $150,000 \mathrm{~m}^{3}$ at the height of $3,400 \mathrm{~m}$, and the Solnechnoye lake with the volume of $190,000 \mathrm{~m}^{3}$ at the height of $3,410 \mathrm{~m}$. The mudflows that could occur after outbursts of these lakes can cause damage to the infrastructure and environment of the nature reserve. The Talgar town is protected by the dam.

There is the Zharsay lake in the Yesik river valley at the height of 3,570 $\mathrm{m}$ that outburst in 1963. Now its depression is empty but after reconstruction of the drainage net it can be fast fill up to hazardous volume. A recreational zone and natural sanctuary are located in the mudflow impact area.

GLOFs hazardous lakes in Zhetysu Alatau are located in the valleys of Korgas, Osek, Aksu, and Sarkan rivers. There is lakes' cascade in the Korgas valley. The most hazardous one is the Kapkan glacial lake at the height of $3,440 \mathrm{~m}$. Its volume measured by bathymetric survey makes 3.7 million $\mathrm{m}^{3}$. The Boskul moraine lake with the volume of 2.1 million $\mathrm{m}^{3}$ is located below it at the height of $3,120 \mathrm{~m}$. The Kazankol lake dammed by a rockfall dam with the volume of 5.2 million $\mathrm{m}^{3}$ is located even lower at the height of 2,230 m. In the case of the Kapkan lake outburst the lakes located lower will also outburst resulting in the mudflow with the volume of more than 10 million $\mathrm{m}^{3}$. The International Center of Border Trading at the border between Kazakhstan and China will be in the impact area of this mudflow. Protective constructions are just being designed.

A hazardous lake with the volume of 2.7 million $\mathrm{m}^{3}$ in the Osek valley is located at the height of $3,400 \mathrm{~m}$. The Lesnovka village is in the impact area of the mudflow that was formed after outburst of this lake. The village has no protection.

There are four hazardous lakes in the Aksu valley: with the volume of 2.2 million $\mathrm{m}^{3}$ at the height of $3,250 \mathrm{~m}$, with the volume of 1.6 million $\mathrm{m}^{3}$ at the height of $3,170 \mathrm{~m}$, with the volume of 1.8 million $\mathrm{m}^{3}$ at the height of $3,180 \mathrm{~m}$ and with the volume of 1.7 million $\mathrm{m}^{3}$ at the height of $3,480 \mathrm{~m}$. The hydro electric power plant in the lower part of the valley and the Zhansugurov town at piedmont plane are located in the impact area of a possible mudflow. There are no protective constructions.

There are two hazardous lake in the Sarkan valley: with the volume of 2.5 million $\mathrm{m}^{3}$ at the height of $3,440 \mathrm{~m}$ and with the volume of 1.2 million $\mathrm{m}^{3}$ at the height of $3,240 \mathrm{~m}$. An outburst mudflow with the volume of 3.2 million $\mathrm{m}^{3}$ occurred in this valley in 1982. It caused damages in the Sarkand town at the piedmont plane. Now this town is protected by the dam.

\section{Conclusion}

The study showed that satellite images together with aerial visual and field surveys allow obtaining the information necessary for assessment of GLOF's damage. To account lakes' volumes one can use empiric dependencies of volumes from lakes' areas. Hazardous level is found according to lake's size, the dam's stability, slope of the below valley and existence of social and economic objects in the possible mudflow zone.

There are 6 hazardous lakes in Ile Alatau. They are located in Kaskelen, Little Almaty, Big Almaty, 
Talgar, and Yesik valleys. There are 8 hazardous lakes in Zhetysu Alatau in Korgas, Osek, Aksu and Sarkan valleys.

\section{Acknowledgement}

The researches funding was made at the cost of the grant under the contract with Science Committee of Ministry of Education and Science of the Republic of Kazakhstan No. 260 as of February 04, 2014.

\section{References}

[1] Huggel, C., Kääb, A., Haeberli, W., and Krummenacher, B. 2003. "Regional-Scale GIS-Models for Assessment of Hazards from Glacier Lake Outbursts: Evaluation and Application in the Swiss Alps." Natural Hazards and Earth System Sciences 3: 647-62.

[2] Huggel, C., Kääb, A., Haeberli, W., Teysseire, P., and F. Paul. 2005. "Remote Sensing Based Assessment of Hazards from Glacier Lake Outbursts: A Case Study in the Swiss Alps." Canadian Geotechnical Journal 39: 316-30.

[3] Iwata, S., Ageta, Y., Naito, N., Sakai, A., and Narama \& Karma, C. 2002. "Glacial Lakes and Their Outburst Flood Assessment in the Buthan Himalaya." Global Environmental Research 6 (1): 3-17.

[4] Ma, D., Tu, J., Cui, P., and Lu, R. 2004. "Approach to Mountain Hazards in Tibet, China." Journal of Mountain Science 1 (2): 143-54.

[5] Popov, N. 1988. "Die Kontrolle gefährlicher Gletscherseen im nördlichen Tienschan." In Proceedings of the Internationals' Symposium Interpraevent, 29-41.

[6] Richardson, S. D., and Reynolds, J. M. 2000. "An Overview of Glacial Hazards in the Himalayas." Quaternary International 65/66 (1): 31-47.

[7] Buchroithner, S., Bajracharya, R., Peters, J., and Baessler, M. 2008. "Identification of Glacier Motion and Potentially Dangerous Glacier Lakes at Mt. Everest Area/Nepal Using Spaceborne Imagery." Natural Hazards and Earth System Sciences 8 (6): 1329-40.

[8] Kääb, A., Huggel, C., Fischer, L. Guex, S., Paul, F., Roer, I., Salzmann, N., Schlaefli, S., Schmutz, K., Schneider,
D., Strozzi, T., and Weidmann, Y. 2005. "Remote Sensing of Glacier and Permafrost-Related Hazards in High Mountains: An Overview." Natural Hazards and Earth System Sciences 5: 527-54.

[9] Frey, H., Haeberli, W., Linsbauer, A., Huggel, C., and Paul, F. 2010. "A Multi-Level Strategy for Anticipating Future Glacier Lake Formation and Associated Hazard Potentials." Natural Hazards and Earth System Sciences 10 (2): 339-52.

[10] Keremkulov, V. A. 1985. "Morph Metric Characteristics and Classification of Moraine Lakes." Mudflows 9: 26-35.

[11] Medeuov, A. R., and Nurlanov, M. T. 1996. Mudflow Phenomena in the Seismic Territories of Kazakhstan. Almaty: Karzhy-Karazhat.

[12] Medeu, A. R. 2011. Mudflow Phenomena in the South-East Kazakhstan. Management Basics. Almaty: Gylym.

[13] Tokmagambetov, G. A., Sudakov, P. A., and Plekhanov, P. A. 1980. "Glacial Mudflows of Zailiyskiy Alatau and Ways of Its Forecast." Data of Glaciological Studies 39: 97-101.

[14] Bolch, T., Peters, J., Yegorov, A., Pradhan, B., Buchroithner, M., and Blagoveshchenskiy, V. 2011. "Identification of Potentially Dangerous Glacial Lakes in the Northern Tien Shan." Nat. Hazards 59 (3): 1691-714.

[15] Bizhanov, N. K, Vinokhodov, V. N., and Kulmakhanov, Sh. K. 1998. Safety and Control of Glacial Mudflows in Kazakhstan. Almaty: Gylym.

[16] Gorbunov, A. P., and Severskiy, E. V. 2001. Mudflows in the Surrouding of Almaty. Almaty: Interligal.

[17] Blagoveshchenskiy, V. P., and Yegorov, A. B. 2009. "The Ile Alatau Range Natural Hazards." In Proceedings of the International Conference on Mitigation of Natural Hazards in Mountain Areas, 15-8.

[18] Baymoldaev, T. A., and Vinokhodov, V. N. 2007. Kazseleshchita-Operative Measurements before and after Disaster. Almaty: Bastau.

[19] Glazirin, G., Schamsutdinov, V., Starygin, G., and Khan, V. 2013. "Inventory of glacial lakes in the territory surrounding Uzbekistan." Hazard Assessment and Outburst Flood Estimation of Naturally Dammed Lakes in Central Asia. Aachen, Germany: Shaker Verlag. 